Prace Literackie LVII

Wrocław 2017

DOI: $10.19195 / 0079-4767.57 .6$

\author{
KAMILA DOMBROWSKA \\ Uniwersytet Gdański
}

\title{
Obraz Oceanii w polskiej literaturze popularnonaukowej
}

Podróż jest motywem powszechnie występującym na łamach literatury. Jeżeli stanowi jej temat przewodni, określa się ją mianem literatury podróżniczej ${ }^{1}$. W Słowniku rodzajów i gatunków literackich zaznaczono, iż celem pisarstwa tego typu jest opis geograficzny miejsc, sposobu wędrówki oraz wrażeń autora ${ }^{2}$. Przekazaniu tych informacji ,towarzyszy zwykle chęć podzielenia się z czytelnikiem wspomnieniami, wrażeniami i refleksjami"3.

Biorąc pod uwagę cechy, które charakteryzują twórczość tego rodzaju, uzasadnione wydaje się umieszczenie jej w kategorii literatury popularnonaukowej oraz popularnej. Próba zdefiniowania tej pierwszej wykazała, że nie jest ona jasno określona. Wyjaśnianie tez, zjawisk, zależności czy też przedstawianie informacji w ramach problematyki naukowej odbywa się w niej w uproszczony sposób, tak aby ułatwić odbiór publikacji i, co za tym idzie, umożliwić jej popularyzację. Przyjmując, że twórcy literatury podróżniczej podjęli się przedstawienia czytelnikom danego kraju (elementów jego kultury, historii), można uznać, że książki podróżnicze mieszczą się w ramach kategorii popularnonaukowej.

Pod pewnymi względami literatura podróżnicza może być włączona także w obręb literatury popularnej, którą w Słowniku literatury popularnej zdefiniowano jako „dziedzinę twórczości literackiej obejmującą utwory przeznaczone dla szerokiego kręgu czytelników i nastawioną na realizację ich potrzeb osobowościowych, na dostarczenie im rozrywki i silnych przeżyć emocjonalnych"4 . Pisarstwo

${ }^{1}$ K. Buczkowska, Literatura podróżnicza faktu niedoceniana nisza turystyki literackiej, „Turystyka Kulturowa” 2009, nr 1, s. 4-13, http://turystykakulturowa.org/pdf/2009_01_01.pdf [dostęp: 21.02.2015].

2 Literatura podróżnicza, [hasło w:] Stownik rodzajów i gatunków literackich, red. G. Gazda, S. Tynecka-Makowska, Kraków 2006, s. 538.

3 Ibidem.

${ }^{4}$ Literatura popularna, [hasło w:] Stownik literatury popularnej, Wrocław 1997 s. 310-316. 
tego typu cechuje schematyczność ${ }^{5}$, co nie przeszkadza twórcom w dostarczaniu odbiorcom intensywnych wrażeń poprzez zawarcie w pracach opisów ekstremalnych przygód bohatera (autora) oraz szokujących zjawisk i zwyczajów ${ }^{6}$.

Paulina Potrykus-Woźniak w Stowniku nowych gatunków i zjawisk literackich pisze, że protoplastami tekstów podróżniczych są starożytne periegezy, czyli komentarze do map ${ }^{7}$. Dla pierwszych form literatury tego rodzaju charakterystyczne było poruszanie się na pograniczu wielu dziedzin, m.in. historii i geografii ${ }^{8}$. Jej upowszechnienie nastąpiło wraz z rozwojem kolei w XIX w., co pozwoliło na intensyfikację podróżnictwa ${ }^{9}$. Do czynników, które wpłynęły na rozkwit podróży i turystyki, należą również: polepszenie warunków ekonomicznych i praw pracowniczych (możliwość wzięcia urlopu, wyższe płace, więcej czasu wolnego), intensywna urbanizacja, $\mathrm{w}$ tym zmiany $\mathrm{w}$ aranżacji przestrzeni publicznej miast nastawionych na zwiedzających (na przykład przebudowa Paryża), udoskonalenie środków komunikacji, a co za tym idzie - wygodniejsze, tańsze i szybsze przemieszczanie się oraz rozwój idei romantycznej opartej na kontemplacji, podziwianiu krajobrazów i wiążące się z tym poszukiwanie nowych miejsc, w których można było tego doświadczać ${ }^{10}$.

Pierwsze opracowania podróżnicze w języku polskim, które zawierały elementy opisu etnograficznego, datuje się na pierwszą połowę XIII w. Prekursorem w tej dziedzinie był Benedykt Polak, który wybrał się do Mongolii z poselstwem ówczesnego papieża Innocentego $\mathrm{IV}^{11}$ i pozostawił po sobie spuściznę w postaci sprawozdania z wyprawy pt. De itinere Fratrum Minorum ad Tartaros.

W niniejszym artykule analizie poddano dzieła literatury podróżniczej poświęconej Oceanii autorów tworzących w XIX i XX w. Jego celem jest zbadanie narracji dotyczącej owego obszaru i jego mieszkańców. Kryterium, na którym oparto wybór omawianych pozycji, była chęć ukazania różnorodności spojrzeń na Oceanię w odmiennych kontekstach historycznych. Wśród autorów książek znaleźli się badacze i podróżnicy — Jan Stanisław Kubary ${ }^{12}$, Aleksander Lech

\footnotetext{
5 Ibidem, s. 216.
}

6 Ibidem.

${ }^{7}$ Literatura podróżnicza, [hasło w:] P. Potrykus-Woźniak, Słownik nowych gatunków i zjawisk literackich, Warszawa-Bielsko Biała 2011, s. 116.

8 Ibidem.

9 Ibidem, s. 119.

10 J. Urry, Spojrzenie turysty, Warszawa 2012, s. 40-51.

11 F. Rosiński, Benedykt Polak - prekursor polskich badań etnologicznych w Azji, [w:] Polskie opisywanie świata. Od fascynacji egzotyka do badań antropologicznych, red. A. Kuczyński, Wrocław 2000, s. 10, 21.

12 Jan Stanisław Kubary (1846-1896) — urodzony w Warszawie podróżnik, etnograf i zbieracz eksponatów. Przez 27 lat z przerwami przebywał na obszarze Oceanii, gdzie oprócz zbierania obiektów zajmował się badaniem kultury, a w szczególności języka jej mieszkańców. 
Godlewski $^{13}$ oraz pisarze, dziennikarze i podróżnicy — Janusz Wolniewicz ${ }^{14}$, Wojciech Dworczyk ${ }^{15}$ oraz Lucjan Wolanowski ${ }^{16}$.

Przedstawienie obrazu Oceanii w literaturze podróżniczej stanowi pretekst do zastanowienia się nad pewnymi jej cechami oraz funkcjami, takimi jak obecność, a także powielanie licznych stereotypów i uproszczeń ${ }^{17}$. Zdaniem Charlesa Stangora i Marka Schallera, ,jako umysłowe reprezentacje świata, stereotypy wpływają na to, jakich informacji na temat członków różnych grup społecznych poszukuje dana osoba, a także jakie informacje zauważa i zapamiętuje" ${ }^{\prime 18}$. W przypadku książek podróżniczych stereotyp odgrywa zatem istotną rolę w przypisywaniu danych cech prezentowanym ludom i miejscom. Literatura może stanowić ponadto swoiste medium, przez które wyrażają się liczne (subiektywne) prawdy, niekoniecznie znajdujące potwierdzenie w nauce. $Z$ tego powodu obserwacje autorów przekazywane na kartach ich prac, czytane następnie przez nieświadomą młodzież i dzieci, mogą przyczyniać się do reprodukowania oraz utrwalania stereotypów. W takim rozumieniu obraz Oceanii można uznać za wytwór zależny od jego twórcy: nie jest obiektywnym i rzeczywistym odwzorowaniem tego obszaru, lecz subiektywną, zdeterminowaną kulturowo wizją pisarza dotyczącą tego obszaru $^{19}$. W dalszej części tekstu przyjrzymy się Oceanii widzianej oczyma polskich podróżników, badaczy, dziennikarzy i pisarzy.

Oceania jest zbiorem wysp położonych na Oceanie Spokojnym. Region ten charakteryzuje się dużym rozproszeniem skupisk ludzkich, co wraz z utrudnionym dostępem, spowodowanym brakiem lądowego połączenia między nimi, stanowi o specyficznym zróżnicowaniu kulturowym tego miejsca. Heterogeniczność została pogłębiona wraz z pojawieniem się tam w XVI w. Europejczyków, co związane było początkowo $\mathrm{z}$ wymianą handlową i poszukiwaniem robotników,

13 Aleksander Lech Godlewski (1905-1975) — polski naukowiec, w którego obszarze zainteresowań znajdowały się antropologia fizyczna, etnografia i etnogeneza mieszkańców Oceanii i Australii. Autor prac naukowych i popularnonaukowych.

14 Janusz Wolniewicz (1929-2006) — dziennikarz, pisarz i podróżnik. Autor kilkudziesięciu książek popularnonaukowych i artykułów podróżniczych. Członek Stowarzyszenia Dziennikarzy Polskich.

15 Wojciech Dworczyk (1927-2012) — polski podróżnik, autor utworów publicystycznych, reportaży i książek opisujących historie z kilkudziesięciu krajów z pięciu kontynentów. Członek Związku Literatów Polskich.

${ }^{16}$ Lucjan Wolanowski (1920-2006) - pochodzący z Warszawy podróżnik, autor licznych reportaży i książek. Pisał m.in. dla „Świata”, „Dookoła Świata”, „Przekroju”, „Kontynentów”, „Życia Warszawy". Członek Związku Zawodowego Dziennikarzy RP, Stowarzyszenia Dziennikarzy Polskich, Związku Literatów Polskich, Stowarzyszenia Pisarzy Polskich.

17 M.F. Gawrycki, W pogoni za wyobrażeniami, Warszawa 2010, s. 114.

$18 \mathrm{Ch}$. Stangor, M. Schaller, Stereotypy jako reprezentacje indywidualne i zbiorowe, przeł. M. Majchrzak, [w:] Stereotypy i uprzedzenia, red. C.N. Macrae, Ch. Stangor, M. Hewstone, Gdańsk 1999, s. 15.

19 Zob. teorie konstruktywistyczne w naukach społecznych, [w:] E. Kosowska, Antropologia literatury. Teksty, konteksty, interpretacje, Katowice 2003, s. 20. 
a następnie z zakładaniem kolonii. W literaturze popularnonaukowej chętnie odnoszono się do tego zagadnienia. Oceania jawi się w niej często jako ofiara działalności Europejczyków, czego przykładem jest wypowiedź szwajcarskiego obywatela rezydującego na Tahiti, przytoczona przez Dworczyka w książce Dzień dobry, Tahiti: ,„pierwsi Europejczycy tak długo grzmocili w Polinezję, aż runęła" ${ }^{20}$. W podobny sposób o relacjach między Europejczykami a miejscowymi i ich skutkach pisał w XIX w. Kubary. Ci drudzy, zdaniem autora, wydają się być „ofiarami europejskiej napaści na miejscową kulturę, która zniekształca ją w negatywny sposób"21. W zbliżony sposób wypowiada się Wolniewicz w książce Vanuatu - czarny archipelag. Autor przyznał, że winę za wiele zbrodni ponoszą Europejczycy. O ofiarach po stronie kolonizatorów (potwierdzając, że bez dokonanej przez nich agresji, nie doszłoby do tak wielu tragedii) napisał, iż ,zabijali ich często jednak nie krajowcy, a pośrednio łotrostwa białych" ${ }^{22}$. Innym przykładem zła wyrządzonego przez europejskich przybyszów był tzw. blackbirding porywanie wyspiarzy do niewolniczej pracy na plantacjach zakładanych m.in. na Fidżi oraz u wybrzeży Australii ${ }^{23}$.

Oceania to również miejsce intensywnego rozwoju gospodarczego i naukowego. Szeroko omawia tę kwestię Godlewski, który pisze, że w 1946 r. Amerykanie wysiedlili ludność z atolu Bikini, aby móc przeprowadzać eksperymenty nad promieniowaniem jądrowym, a w szczególności jego wpływem na zwierzęta i rośliny ${ }^{24}$. Anglicy nie pozostawali w tyle i prowadzili swoje badania na wyspie archipelagu Fanning w latach $1956-1958^{25}$. Po podpisaniu traktatu o zaprzestaniu eksperymentów jądrowych przez oba państwa w 1962 r. doświadczenia rozpoczęła Francja. Obszarem jej działań było Tahiti, o czym wspominają Wolanowski ${ }^{26}$ i Godlewski. Ten drugi zwraca uwagę na zmiany, które były skutkiem pojawienia się na wyspach żołnierzy i marynarzy oraz ich poczynań. Liczne samochody, ciężarówki, oddziały wojskowe oraz budowa nowych budynków zaburzały poczucie dotychczasowej harmonii mieszkańców. Nieodwracalne zmiany nastąpiły również w stylu życia tubylczych robotników, w tym młodych ludzi, którzy porzucali swoje rodzinne wioski, aby zarabiać większe pieniądze 27 .

Oprócz prowadzenia badań nad energią jądrową na Oceanii zakładano kopalnie korzystające z miejscowych źródeł geologicznych. O jednym z takich miejsc pisze Wolanowski. Makatea, wyspa należąca do archipelagu Tuamotu, posiadała liczne złoża fosforytów, które rząd francuski zdecydował się wydobywać i eks-

20 W. Dworczyk, Dzień Dobry, Tahiti, Warszawa 1981, s. 149.

21 J. Kubary, Wyspy cieptych mórz. Jana Stanisława Kubarego notaty z podróży po Mikronezji, red. M. Jędrusik, M. Jackowska, Warszawa 1997, s. 157.

22 J. Wolniewicz, Vanuatu - czarny archipelag, Warszawa 1984, s. 59.

${ }^{23}$ Ibidem, s. 8, 9 .

24 L.A. Godlewski, Czar dalekiej Nuku Hiva, Wrocław 1971, s. 224.

25 Ibidem, s. 225.

${ }^{26}$ L. Wolanowski, Ocean nie bardzo spokojny, Warszawa 1967, s. 80, 81.

27 L.A. Godlewski, op. cit., s. 228, 229. 
portować. Reporter postanowił spędzić jeden dzień w towarzystwie górników. Robotnicy, którzy od świtu do zmierzchu pracowali nad wydobyciem fosforytu, po powrocie do domu kładli się spać. Ich jedynym wolnym dniem była niedziela. Co za tym idzie, alkohol sprzedawano pracownikom tylko w soboty i wtedy właśnie, na jedną noc, zakwitało życie na wyspie. Autor stwierdzając „A przecież to też Polinezja..."28, wyraża melancholijną myśl, która każe zastanowić się nad tym, jak bardzo mogły się zmienić obyczaje tutejszej (i sprowadzonej z całej Polinezji) ludności.

Piękno, rajskość i niebiańskość krajobrazu Oceanii są charakterystycznymi elementami jej opisu. Dworczyk na przykładzie Tahiti wyjaśnił, że legenda tego miejsca wzięła się ze wspomnień przywożonych przez pierwszych europejskich podróżników, dla których był to „,raj na ziemi”"29. Co ważne, idylliczne w książce są zarówno warunki środowiskowe, jak i sami mieszkańcy wysp. Autor nie kryje fascynacji ich sposobem życia, charakterem, a także wyglądem ${ }^{30}$.

W podobny sposób wypowiada się Wolniewicz, który w swojej książce zwraca uwagę na niecodzienne warunki panujące na Vanuatu. Wskazuje on, że nie trzeba się bardzo starać, aby zanurzyć się w pięknie i wyjątkowości tamtejszego świata — ,nic się nie działo, niewiele było widać, a mimo to czułem się po uszy zanurzony w egzotyce"31, gdyż

człowiek, zawieszony w toni ciepłych, tropikalnych mórz, nie może wnosić żadnych pretensji do matki natury. [...] Zawsze jest pięknie, ciekawie. Wystarczy jedna mała rybka tarzająca się w fioletowych gałązkach ukwiału, wystarczą układające się na dnie refleksy słońca z powierzchni wody, aby zachwycić się tym intrygującym światem ${ }^{32}$.

Inny, odbiegający od rajskiego, obraz Oceanii ukazują opisy z głębi lądów, które są niebezpieczne, a poruszanie się tam jest wysoce ryzykowne. Zarówno Wolniewicz, jak i Dworczyk w pracach dotyczących Nowej Gwinei prezentują właśnie tę „ciemną stronę” raju, wyrażając przy tym obawę przed podróżowaniem po jej obszarze. Wolniewicz po dobiciu małym statkiem do wsi Omaumere, gdzie miał przebywać przez kilka następnych dni, w następujący sposób opisuje swoje doznania: „Kiwam głową, ale czuję się niewyraźnie. Nie przyznam się przecież, ale mam lekkiego pietra"33. Przykład ryzyka związanego z przemieszczaniem się zauważyć można również w opisie lądowania samolotu, którym podróżował Wolniewicz ${ }^{34}$. Zaprezentowana w nim narracja ukazuje go jako odkrywcę nieznanego, trudno dostępnego terenu, nonszalancko reagującego na zagrożenie poprzez wypicie swojego „ostatniego” piwa. Podobny sposób kreowania się polskich

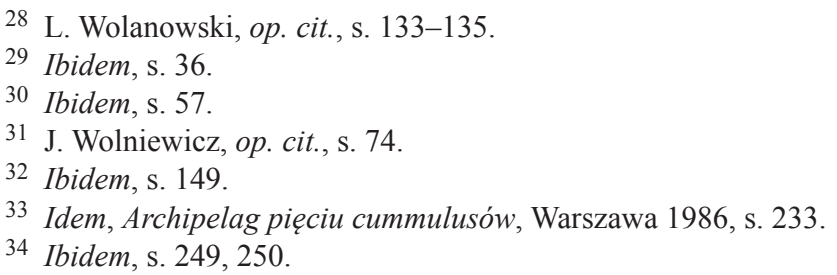


podróżników odnotował Marcin Florian Gawrycki ${ }^{35}$, który podkreślił, iż dążą oni w opisywanych przez siebie wyprawach do odkrycia ostatnich nietkniętych cywilizacją miejsc i osób ${ }^{36}$. Badacz ten odwołał się do Claude'a Lévi-Straussa i wskazał na pewien paradoks: dawniej, gdy Europejczycy rozpoczynali wyprawy w nowe miejsca, mieli okazję poznać świat w ogromnej mierze różny od ich własnego, ale w niewielkim stopniu ową możliwość docenili. Współcześnie, gdy zainteresowanie różnorodnością jest duże, coraz ciężej jest do niej dotrzeć ${ }^{37}$.

W Oceanii niebezpieczne wydają się również zwierzęta. Wolniewiczowi na Nowej Gwinei we znaki dały się żaby, które tak głośno rechotały, że początkowo wziął je za nosorożca ${ }^{38}$. Podróżnik narzekał także na moskity, których ukąszenia przypominały ukłucia sztyletem - owady wręcz ,żarły [...] na surowo" ${ }^{39}$. Ponadto na wyspie uważać należy na krokodyle, występujące tam zarówno na wybrzeżu, jak i w głębi lądu ${ }^{40}$. Nieco inaczej sytuacja wygląda na Tahiti, gdzie — jak stwierdził Dworczyk - z wyjątkiem rekinów, właściwie nie ma niebezpiecznych zwierząt, takich jak węże czy krokodyle ${ }^{41}$.

Pozostając w wątku odnoszącym się do zwierząt, należy podkreślić, że autorzy zauważyli wśród ludów zamieszkujących wyspy Oceanu Spokojnego ważną rolę świń, zarówno pod względem obrzędowym, jak i hodowlanym. Piszą, że właściciele często sypiają ze swoimi świniami w jednym pomieszczeniu, spędzają z nimi dużo czasu (szczególnie kobiety, które są nawet skłonne do karmienia ich własną piersią) i są do nich bardzo przywiązani ${ }^{42}$. Następnie jednak, na wielkich uroczystościach świniobicia, tańczą, śpiewają, zabijają je i spożywają ${ }^{43}$. Sing-singi, bo o nich mowa, pełnią ważną funkcję w życiu mieszkańców. Dają możliwość zaprezentowania tradycyjnych strojów, śpiewów i tańców. W trakcie biesiadowania nawiązywane są relacje z często oddalonymi plemionami, z którymi na co dzień kontakt jest utrudniony ${ }^{44}$. Ciekawą, choć poddaną licznej krytyce ${ }^{45}$, interpretację tego zjawiska zaproponował w latach 60. XX w. amerykański antropolog Roy

35 Marcin Florian Gawrycki (ur. 1975) — polski politolog i latynoamerykanista, profesor nadzwyczajny Uniwersytetu Warszawskiego oraz Uniwersytetu Przyrodniczego w Poznaniu.

36 M.F. Gawrycki, op. cit., s. 74.

37 Ibidem, s. 71.

38 J. Wolniewicz, Archipelag..., s. 230.

39 Ibidem, s. 229, 230.

40 W. Dworczyk, My, dzicy Papuasi, Warszawa 1975, s. 277.

41 Ibidem, s. 56.

42 Ibidem, s. 166; J. Wolniewicz, Vanuatu..., s. 50.

43 W. Dworczyk, My, dzicy..., s. 166.

${ }^{44}$ Na Nowej Gwinei są to przede wszystkim kłopoty z transportem na duże odległości: kiepski stan dróg i komunikacji publicznej, górzyste, trudne do przebycia tereny.

45 Pierwsze prace antropologa kulturowego krytykowano m.in. za zbyt małe skupienie się na sprawczości jednostek, a zbyt duże na systemach społecznych. Zarzucano mu również podejście naturalistyczne. Zob. A. Biersack, Od „,nowej ekologii” do nowych ekologii, przeł. M. Bucholc, [w:] Badanie kultury. Elementy teorii antropologicznej - kontynuacje, red. M. Kempny, E. Nowicka, Warszawa 2006, s. 193-214. 
Rappaport. W pracy Pigs for Ancestors: Ritual Ecology of a New Guinea People, na przykładzie nowogwinejskiego klanu Tsembaga z plemienia Maring, przedstawił zjawisko o nazwie kaiko, z którym związany był cykl zrytualizowanych zachowań odpowiednich dla czasu pokoju i walk. Okres pokoju rozpoczynał się od zasadzenia symbolizującego go drzewka rumbim. W tym czasie zajmowano się m.in. hodowlą świń, których nie można było zabijać. Rosnąca liczba zwierząt wiązała się z coraz mniejszą możliwością ich kontroli, co wpływało na większą liczbę konfliktów wśród ludzii ${ }^{46}$. W pewnym momencie mężczyźni rozpoczynali przygotowania do kaiko. Wyrywano drzewko, szukano sojuszników w konfliktach oraz organizowano świniobicie. Według Rappaporta zabicie świń symbolizowało ofiarę z ludzi, którą składano dla przodków w podziękowaniu za dotychczasową opiekę nad grupą i zwierzętami ${ }^{47}$. Poza tym w zamian za ofiarę Tsembaga oczekiwali od nich pomocy podczas ewentualnych walk ${ }^{48}$. Rytuał posiadał również charakter użytkowy. Społeczność zapewniała sobie dostęp do zasobów żywności dzięki uczcie, na której potrzeby wytrzebiano świnie zjadające zbyt dużo pokarmu i niszczące grunty ${ }^{49}$. Podczas kaiko regulowano również relacje z sąsiednimi plemionami. Prowadzono negocjacje, a jeśli te nie łagodziły napięć, dochodziło do walk o zasoby naturalne potrzebne do zachowania ciągłości grupy ${ }^{50}$.

Metaforyczna magia Oceanii to nie tylko krajobraz oraz zwierzęta. Obejmuje ona także coś, co na całej ziemi, bez względu na miejsce, epokę czy kulturę, jest takie samo - upływ czasu (ujęty w skalarnej wielkości fizycznej). W poszczególnych kulturach odczuwanie czasu może się różnić. Autorzy doświadczyli szeregu sytuacji, z których wyciągnęli wniosek, zwerbalizowany przez Wolniewicza następującymi słowami: „Na Pacyfiku czas nie jest tak bezcenny, jak w Europie” ${ }^{\text {". }}$. Przekłada się to m.in. na niedogodności związane z umawianiem się na konkretne godziny. Według Dworczyka nawet jednodniowe spóźnienia nie należą na Tahiti do rzadkości ${ }^{52}$ — „najgorzej jest tylko z tą punktualnością. Spóźniają się wszyscy. Ale to jest Oceania, gdzie czas należy do pojęć niewymiernych"53.

$\mathrm{Na}$ obraz Oceanii w polskiej literaturze podróżniczej składają się także ludzie, których autorzy spotykają w trakcie wojaży. Ich uwagę przyciągają różnice w wyglądzie zewnętrznym mieszkańców. Najwięcej miejsca tej kwestii poświęcił Godlewski, który wyjaśnia, że celem jego badań nad składem antropologicznym ludności Oceanii była chęć porównania podobieństw między mieszkańcami po-

46 R. Rappaport, Pigs for Ancestors: Ritual Ecology of a New Guinea People, Oxford 2000, s. 166.

47 Ibidem, s. 167.

48 Ibidem, s. 179, 180.

49 Ibidem, s. 159.

50 Ibidem, s. 28, 153.

51 Ibidem, s. 48.

52 W. Dworczyk, op. cit., s. 99.

53 Ibidem, s. 158. 
szczególnych wysp ${ }^{54}$. Z jego badań wynika, że ludy Oceanii można podzielić na wywodzące się z rejonu peryferyjnego (zespół staropolinezyjski) oraz centralnej i północnej Polinezji ${ }^{55}$. Różnią się one między sobą na przykład wielkością głowy (osobniki z drugiej grupy posiadają nieco mniejszą ${ }^{56}$ ). Godlewski uważa, że jest to cenna wiedza w badaniach nad sposobem migracji ludów Oceanii, a także ich etnogenezą ${ }^{57}$.

Pozostali autorzy skupiali się raczej na bardziej widocznych cechach fizycznych, które nie wymagają dokładniejszych pomiarów i są możliwe do zaobserwowania przez każdego podróżnika. W opisach mieszkańców nagminnie pojawia się przymiotnik „czarny”, który dziś może wydawać się nacechowany pejoratywnie. Należy stanowczo podkreślić, że nie posiada on takiego wydźwięku w analizowanych pracach. Przykładem tego mogą być słowa Wolniewicza: „Patrzyłem, jak ściekały im strumyki potu po obliczach czarnych jak melanezyjska noc"58.

Literatura podróżnicza zawiera także opisy charakterów mieszkańców Oceanii. W opinii Dworczyka Tahitańczycy, których często nazywał Polinezyjczykami, wydają się równie bliscy ideału jak ich ziemia ${ }^{59}$. W swojej pracy kreuje taki oto ich obraz: rozgadani gawędziarze ${ }^{60}$ którzy niezmiernie kochają swoje dzieci ${ }^{61}$, lecz nie przepadają za manifestowaniem tych uczućc ${ }^{62}$. Odznaczają się charakterem, który nie pozwala im długo usiedzieć w jednym miejscu ${ }^{63}$; aby zrobić coś porządnie, naprawdę muszą to lubić64 . Wyznają zasady: „mało pracować — dużo wypoczywać” i „lepiej być leniwym niż martwym”65. Należy zaznaczyć, że taki portret mieszkańców Oceanii jest znacznie uproszczony, autor nie mógł w ciągu krótkiego pobytu poznać dostatecznie wielu osób (nie mógł poznać ich głębiej), aby przygotować rzetelną charakterystykę ludu.

W podobnym tonie wypowiada się Kubary o mieszkańcach wysp Samoa. Autor uważa, że „krajowcy są nader obrazowi, poetyczni, towarzyscy i gościnni”"66, gdyż „Samoańczyk rozwinął w sobie ducha pełnego wyobraźni, hojnej gościnności i nieoględnej dobroduszności”67.

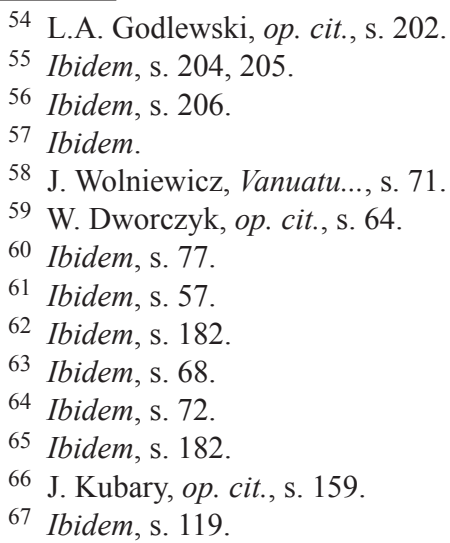


Obok pochlebnych opinii wyrażanych o mieszkańcach Oceanii spotykamy również mniej pozytywne. Przykładem może być wypowiedź Dworczyka w książce My, dzicy Papuasi, w której zdecydował się nazwać kobiety przygotowujące na posiłek węża - wiedźmami ${ }^{68}$. Nie sposób dociec powodów, jakie kierowały autorem w momencie pisania tych słów.

O mieszkańcach Oceanii wspomina także Wolniewicz. W pracy Vanuatu czarny archipelag zamieścił wypowiedzi kapitana statku, którym się poruszał, i jego załoganta, Dominika. Pierwszy wyznał, że tubylcy są dziećmi natury, które są lekkomyślne, drugi zaś potwierdził to i dodał, że brak u nich zdolności przewidywania $^{69}$.

Istotnym składnikiem relacji o życiu mieszkańców Oceanii, który przywołani autorzy często umieszczali w swoich książkach, jest ich konfliktowa natura, co zostało szczególnie wyeksponowane w przypadku ludów Nowej Gwinei. O tym, że walki były najbardziej lubianym przez nich zajęciem, pisze m.in. Wolniewicz ${ }^{70}$. Dworczyk przytacza z kolei historię jednego z mieszkańców wioski o genezie nieustających walk ${ }^{71}$. Według informatora pewnego dnia dwie wioski popadły w spór dotyczący świni, w wyniku którego jedni napadli na drugich i zabili kilka osób, co stało się przyczyną zemsty tych, którzy pozostali przy życiu. Chęć zemsty, która jest silnie uwarunkowana poczuciem honoru mieszkańców, napędzała w ten sposób dalsze spory.

Częste popadanie w konflikty zaobserwował u mieszkańców Oceanii także Kubary, który napisał, że „na największej części wysp oceanu, wojna jest dla krajowca zabawą, której prawie pożąda i na którą udaje się wystrojony jak najwspanialej"72.

W ramach opisu ciemniejszych stron zwyczajów ludności tego obszaru nie może zabraknąć wzmianek o kanibalizmie. Oceania wydaje się ostoją ludożerstwa: albo jeszcze praktykowanego, albo niedawno zaniechanego, albo już od dawna zarzuconego, ale wciąż będącego w pamięci mieszkańców. Zagadnieniem popularności historii związanych z antropofagią zajął się antropolog Wiliam Arens, który zebrał i przeanalizował przykłady opisu kanibalizmu w literaturze. Co ważne, są one charakterystyczne także dla tych zawartych w książkach polskich podróżników. W pracy zatytułowanej Mit ludożercy. Antropologia i antropofagia (2010) Arens zauważył, że tak naprawdę nie ma żadnego udowodnionego naukowo przypadku antropofagii, gdyż

wyłączając przypadki związane z koniecznością biologicznego przetrwania, nie mogłem odnaleźć w jakiejkolwiek formie należytych dowodów występowania kanibalizmu jako zwyczaju w jakim-

\footnotetext{
68 W. Dworczyk, My, dzicy..., s. 96.

69 J. Wolniewicz, Vanuatu..., s. 90.

${ }^{70}$ Idem, Archipelag..., s. 270.

71 W. Dworczyk, My, dzicy..., s. 59.

72 J. Kubary, op. cit., s. 93.
} 
kolwiek społeczeństwie. Mnożą się plotki, podejrzenia, lęki i oskarżenia, lecz prawie nie ma relacji terenowych z pierwszej ręki ${ }^{73}$.

Według badacza W. Arensa jednym z pierwszych, który sam przeżył spotkanie z ludożercami, był XVI-wieczny żeglarz Hans Staden ${ }^{74}$. Analiza pozostawionej przez niego relacji umożliwiła Arensowi wskazanie jej niedociągnięć. Przede wszystkim za wątpliwą uznał możliwość rozmowy żeglarza z plemieniem Indian Tupinamba, od którego, jak twierdził, zdobył informację o praktykach kanibalistycznych. Tezę tę badacz uzasadnił nieznajomością przez Stadena języka plemienia Tupinamba ${ }^{75}$.

Kolejne opowieści o kanibalizmie tworzone były według Arensa na kanwie tej właśnie historii. Badacz wyjaśnił następująco mechanizm, który potencjalnie kierował ich autorami:

Popełnianie tego rodzaju plagiatu, które względem innych epok i miejsc zostało dowiedzione, w relacjach podróżników do obcych krajów było wręcz powszechne, w związku z ich dążeniem do uniknięcia sytuacji, w której opisy musiałyby przegrać z barwnymi relacjami z tych samych stron, podawanymi przez innych podróżników ${ }^{76}$.

Polscy podróżnicy i badacze wątek kanibalizmu poruszali czasami już na pierwszych stronach swoich dzieł. Wolniewicz wprowadzając czytelnika w świat Nowej Gwinei, zauważył, że żyją tam „tubylcy, wśród których ludożercy nie należeli do rzadkości"77. Ludożercy żyli także wśród Maorysów, o czym pisze Wolanowski ${ }^{78}$. W jego opinii lud ten wierzy, iż dusza ludzka jest niejadalna, jednak nic nie stoi na przeszkodzie, aby zjeść ciało i w ten sposób wejść w posiadanie czyichś cech, na przykład męstwa lub siły. $Z$ dozą humoru autor zauważył, że „tak jak ludzie antyku wracali z boju z tarczą lub na tarczy, tak i Maorysi czas po bitwie spędzali nad garnkiem lub w garnku"79.

Utwory literackie omawiane w niniejszym artykule prezentują Oceanię w relatywnie uproszczony i jednolity sposób. Jest postrzegana jako ofiara europejskiego kolonializmu, którego skutki dotknęły nie tylko jej mieszkańców, lecz również środowisko naturalne. Agresja, choroby, uniemożliwianie kontynuowania tradycyjnego stylu życia, handel niewolnikami, okradanie z surowców naturalnych, przejmowanie terenów pod budowę placówek badawczych i kopalń — to tylko niektóre z wątpliwych zasług Europejczyków na tym obszarze. Kolejną cechę wspólną relacji polskich podróżników stanowi akcentowanie pięknego, rajskiego i wyjątkowego krajobrazu Oceanii, któremu poświęcają wiele barwnych opisów. Najczęściej wyróżniano pod tym względem Tahiti oraz Vanuatu. Rajski obraz

\footnotetext{
73 W. Arens, Mit ludożercy. Antropologia i antropofagia, przeł. W. Pessel, Warszawa 2010, s. 52.

${ }^{74}$ Ibidem, s. 53-56.

75 Ibidem, s. 55, 56.

76 Ibidem, s. 62, 63.

77 J. Wolniewicz, Archipelag..., s. 214.

78 L. Wolanowski, op. cit., s. 234.

79 Ibidem.
} 
Oceanii autorzy skontrastowali z niebezpieczeństwami związanymi z przemieszczaniem się po Nowej Gwinei oraz zwierzętami, które ją zamieszkują. Podczas wypraw podróżnicy doświadczali ryzykownych przelotów i rejsów, spotkań z krokodylami, moskitami, a nawet żabami o sile głosu nosorożców. Wiele miejsca w literaturze podróżniczej poświęcono także ludności Oceanii. Jako przyjaznych, dobrodusznych i towarzyskich odbierano mieszkańców Tahiti oraz Samoa. Mniej pozytywnie pisano o obywatelach Vanuatu i Nowej Gwinei, którym przypisywano konfliktowość oraz tradycje kanibalistyczne.

Zbieżność narracji dotyczących Oceanii może wynikać z pobudek podobnych do tych, którymi Arens wyjaśnia popularność motywu kanibalizmu w literaturze podróżniczej. Relacje opisujące egzotyczne i niebezpieczne miejsca, fascynujące przygody oraz mrożące krew w żyłach historie przyciągają uwagę czytelników. Ten atrakcyjny świat autorzy rozbudowali ponadto licznymi środkami stylistycznymi, do których należą m.in. animizacja, ironia oraz epitety. Obraz Oceanii w polskiej literaturze podróżniczej można zatem uznać za barwny, lecz należy pamiętać przy tym, iż jest on również uproszczony. Teza ta każe wątpić w wiarygodność pisarstwa tego typu, szczególnie, jeśli pod uwagę weźmiemy zawarte w nim cechy europocentryzmu. Jego znamiona stają się dobrze widoczne, gdy odwołamy się do kryteriów wyróżniających ową postawę, zaproponowanych przez Arjuna Appaduraia w pracy $O$ wtaściwe miejsce w hierarchii ${ }^{80}$. Analizując obraz Indii, badacz dostrzegł trzy mechanizmy, które wykorzystywano do jego konstrukcji ${ }^{81}$. Pierwszym z nich jest esencjalizacja, czyli przypisywanie zjawiskom, osobom, miejscom czy też przedmiotom pewnych niezmiennych cech, co w przypadku narracji dotyczącej Oceanii widoczne jest m.in. w utożsamianiu ludności Nowej Gwinei z konfliktowością i praktykami kanibalistycznymi, a mieszkańców Tahiti z łagodnością i towarzyskością. Drugim kryterium jest totalizowanie, które wiąże się z nadawaniem dużego, wręcz totalnego, znaczenia mniej ważnym i szczególnym cechom społeczności, co w relacjach z Oceanii znajduje odzwierciedlenie w odwołaniach do antropofagii. Ostatnim narzędziem wymienionym przez Appaduraia jest egzotyzacja, która opiera się na akcentowaniu różnic między tym,

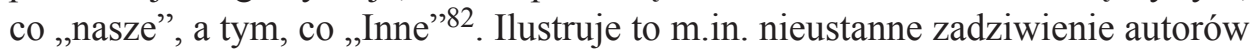
życiem lokalnych mieszkańców, na przykład sposobem pojmowania przez nich czasu, a także podkreślanie różnych od polskich cech krajobrazu naturalnego.

Podobieństwa obecne na łamach analizowanych w niniejszym artykule prac nie wykluczają licznych różnic pomiędzy nimi. Jak wspomniano we wstępie opracowania, utwory literackie stanowią sumę wiedzy, doświadczeń, zakorzenionych wzorów i postaw, które miały wpływ na piszących je autorów, a te każdy z nich ma

${ }^{80}$ Kryteria te wykorzystał również Gawrycki na łamach publikacji przytaczanej w niniejszym artykule.

81 A. Appadurai, O właściwe miejsce hierarchii, przeł. W. Dohnal, [w:] Amerykańska antropologia postmodernistyczna, red. M. Buchowski, Warszawa 1999, s. 235-236.

82 M.F. Gawrycki, op. cit., s. 159. 
inne. W książkach podróżników widoczne jest to m.in. w różnym stopniu przygotowania naukowego poszczególnych twórców, szczególnie w dziedzinie etnografii. Większą wiedzę w tym zakresie, w porównaniu do reszty pisarzy, wykazali Kubary i Godlewski. Kolejną różnicę stanowi odmienność wątków poruszanych przez autorów, wynikająca na przykład z ich wykształcenia, zawodu czy osobistych zainteresowań. Godlewski, jako antropolog, zwracał w pracach większą uwagę na aspekty etnogenezy i cech fizycznych rodzimych mieszkańców Oceanii, Wolniewicz zaś, z racji zainteresowania sztuką ludową, opisywał relacje $\mathrm{z}$ wizyt na miejscowych targach ${ }^{83}$. Różnice w wizerunku Oceanii dostrzec można także $\mathrm{w}$ sposobie przedstawiania poszczególnych wysp. Z jednej strony mamy na przykład idylliczne Tahiti i jej przyjaznych obywateli, a z drugiej niepokojącą Nową Gwineę z konfliktowymi mieszkańcami i niebezpiecznymi zwierzętami.

Podstawę obrazu Oceanii w polskiej literaturze podróżniczej stanowi w głównej mierze kanon kilku przypisywanych jej cech. Jest to ofiara europejskiego handlu oraz kolonizacji i, w zależności od miejsca, charakteryzuje się rajskim krajobrazem, niebezpiecznymi zwierzętami, tradycjami kanibalistycznymi i konfliktowością lub życzliwością wyspiarzy. Wizerunek ten zdeterminowany jest przez autorów publikacji: ich wiedzę, doświadczenia oraz przekonania. Charakterystyczne dla niego są liczne uproszczenia i etnocentryzm, wynikające z chęci przykucia uwagi czytelnika, a także ułatwienia przyswojenia informacji zawartych w publikacji. Z powyższego powodu literatura podróżnicza wykorzystywana w celu popularyzacji wiedzy może wpływać na zniekształcanie rzeczywistego obrazu miejsc, które opisuje, oraz powielanie stereotypów na jego temat.

\section{Oceania's image in Polish popular science literature}

\section{Summary}

In Polish popular science literature Oceania is seen as a place characterized by the heavenly landscapes and friendly people but also as an area known from its cannibalistic tradition, dangerous jungle and animals. Article is analysis of this image and shows the most popular characteristics of this area which includes author's point of view and specific measures applied by them, for example stereotypes, ethnocentrism and stylistic devices. Disclosure of them is very important to understand how literature influences on books recipients and their worldview. This is the main goal of this work.

83 J. Wolniewicz, Vanuatu..., s. 178. 